\title{
8
}
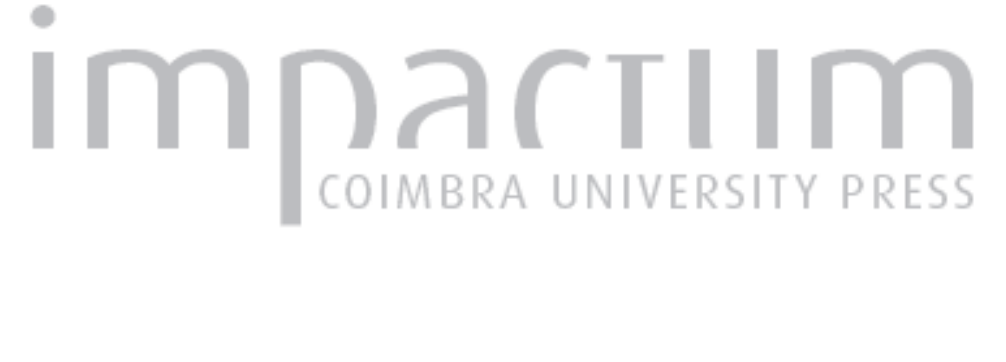

\section{Pessoas-livros: o Arquivo Bibliográfico de Fernando Pessoa}

Autor(es): $\quad$ Sepúlveda, Pedro

Publicado por: Centro de Literatura Portuguesa

URL persistente:

URI:http://hdl.handle.net/10316.2/34682

DOI:

DOI:http://dx.doi.org/10.14195/2182-8830_2-1_3

Accessed : $\quad$ 26-Apr-2023 10:51:48

A navegação consulta e descarregamento dos títulos inseridos nas Bibliotecas Digitais UC Digitalis, UC Pombalina e UC Impactum, pressupõem a aceitação plena e sem reservas dos Termos e Condições de Uso destas Bibliotecas Digitais, disponíveis em https://digitalis.uc.pt/pt-pt/termos.

Conforme exposto nos referidos Termos e Condições de Uso, o descarregamento de títulos de acesso restrito requer uma licença válida de autorização devendo o utilizador aceder ao(s) documento(s) a partir de um endereço de IP da instituição detentora da supramencionada licença.

Ao utilizador é apenas permitido o descarregamento para uso pessoal, pelo que o emprego do(s) título(s) descarregado(s) para outro fim, designadamente comercial, carece de autorização do respetivo autor ou editor da obra.

Na medida em que todas as obras da UC Digitalis se encontram protegidas pelo Código do Direito de Autor e Direitos Conexos e demais legislação aplicável, toda a cópia, parcial ou total, deste documento, nos casos em que é legalmente admitida, deverá conter ou fazer-se acompanhar por este aviso. 


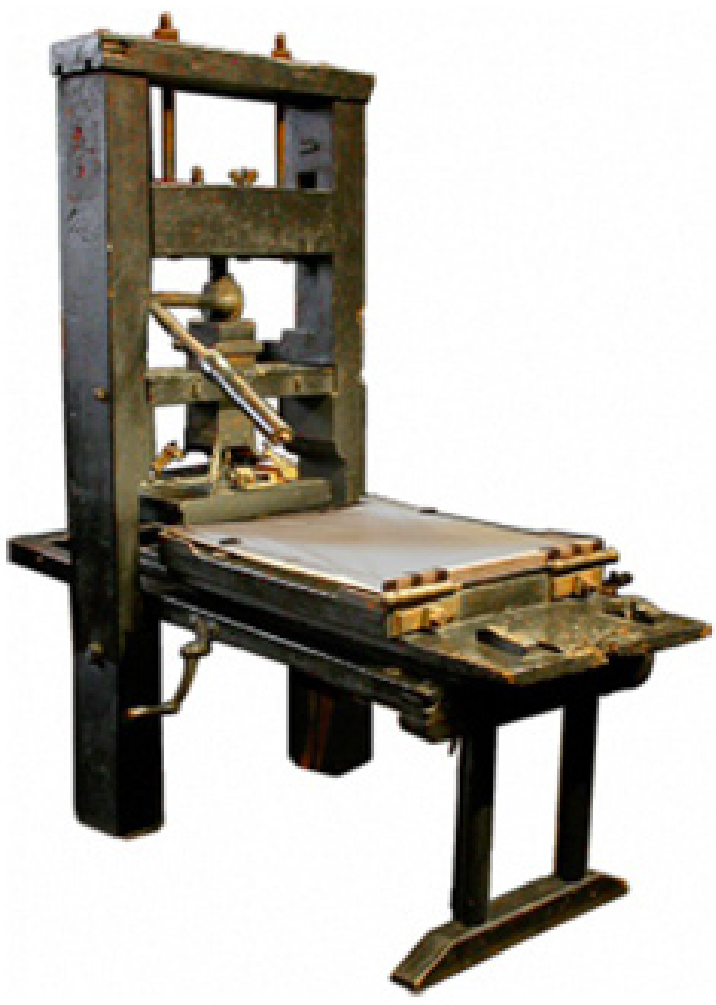

Vol. 2.1 (2014)

ISSN 2182-8830

'Livro e Materialidade'

Abel Barros Baptista (org.) 


\title{
Pessoas-livros: O Arquivo Bibliográfico de Fernando Pessoa PedRo SEPúlveda
}

\author{
Universidade Nova de Lisboa
}

Investigador de Pós-Doutoramento FCT

\begin{abstract}
Resumo
Apesar de a obra de Fernando Pessoa estar contida principalmente nos quase 30000 papéis que compõem o arquivo hoje à guarda da Biblioteca Nacional de Portugal, é possível demonstrar como este arquivo é composto por materiais de cariz bibliográfico, que o associam ao suporte do livro. Contrariamente a uma ideia corrente de Pessoa como alguém que não escreveu livros e deixou apenas papéis avulsos, esta evidência material mostra que o poeta concebia uma ideia de livro e de conjunto de livros que condicionava o seu modo de escrita. Este artigo tem como propósito contextualizar e precisar as preocupações de Pessoa com a materialidade de um suporte distinto daquele em que se encontra a maior parte da sua obra, analisando diversos testemunhos desta dimensão bibliográfica da sua escrita. Palavras-Chave: Fernando Pessoa; Arquivo; Livro; Edição; Poesia; Modernismo.
\end{abstract}

\section{Abstract}

Although Fernando Pessoa's work mostly exists in the nearly 30,000 pieces of paper that form the archive held by the Portuguese National Library, it is possible to show how this archive is composed by bibliographical materials, which link it to the book as a medium. Against the common idea of Pessoa as someone who didn't write books and only left individual pieces of paper, this material evidence shows that the poet conceived an idea of the book and of a set of books, which conditioned his way of writing. This article follows the purpose of contextualizing and determining Pessoa's concerns with the materiality of a medium different than the one which contains the greater part of his work, by analyzing several evidences of this bibliographical dimension of his writing. Keywords: Fernando Pessoa; Archive; Book; Edition; Poetry; Modernism.

$\mathbf{N}$ a famosa e mais antiga fotografia da arca de Pessoa de que há conhecimento vê-se um conjunto de grandes envelopes enchendo uma arca posicionada à frente de uma estante com livros (cf. Figura 1). Esta imagem, possuindo uma aura de autenticidade hoje irrecuperável, pelo facto de a maioria dos papéis contidos na arca estar guardada na Biblioteca Nacional de Portugal e o móvel ter sido adquirido por um proprietário anónimo, é significativa pelo menos por dois motivos. $\mathrm{O}$ primeiro encontra-se expresso numa descrição feita por Maria Aliete Galhoz a respeito da composição da "célebre e verídica arca dos seus papéis", segundo a qual esta "guardava primitivamente sacos de papel e embrulhos atados com cordéis, contendo os seus escritos num primeiro delineamento de 
classificação, e tendo escrito por fora, de seu punho [de Pessoa], o teor dos conteúdos, às vezes intitulado, outras vezes não" (216). O segundo motivo tem que ver com a relação estabelecida pela proximidade espacial entre dois tipos de suporte de escrita distintos, os papéis da arca e os livros da estante.

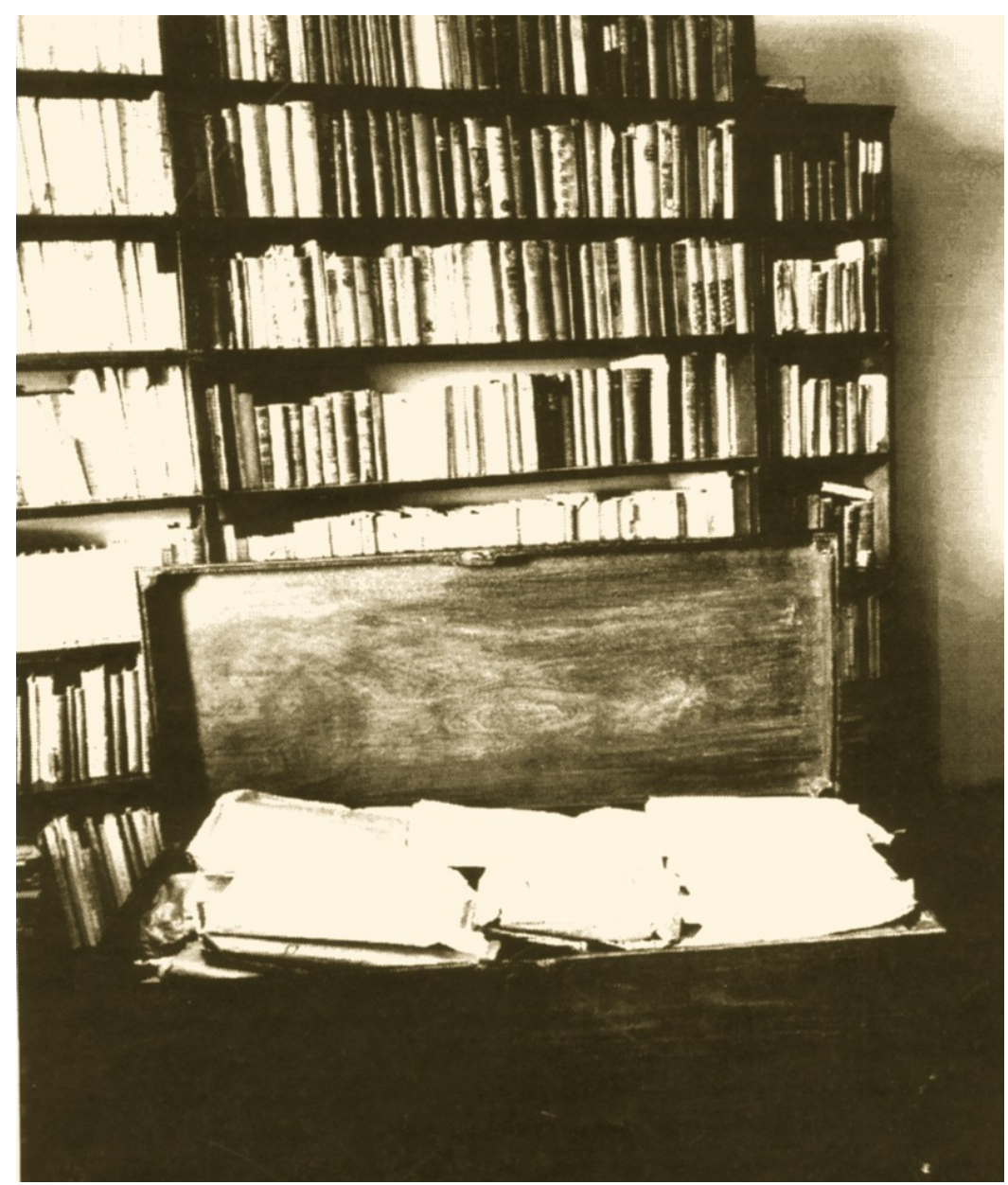

Figura 1. Coleção Particular.

O primeiro motivo de interesse desta imagem consiste na reprodução fotográfica de embrulhos entretanto desaparecidos e que, ampliada pela descrição de Galhoz, nos leva a entender melhor o modo como Pessoa terá legado os ditos papéis à posteridade. Estes papéis estariam organizados em embrulhos e deste modo classificados, incluindo por vezes uma indicação de título. Este modo de organização dos papéis perdeu-se na reorganização do arquivo, ainda que possa ter fornecido aos seus organizadores indicações que 
nem sempre terão sido seguidas. ${ }^{1}$ Esta organização justifica metaforicamente a proximidade entre estes papéis e os livros da estante. Não se trata afinal de papéis avulsos, sem princípio de ordem, e a ordenação arquivística do autor aproxima-os de uma ideia de reunião que carateriza os volumes.

O propósito deste artigo consiste em demonstrar como, contrariamente a uma ideia corrente de Pessoa como alguém que não escreveu livros e deixou apenas papéis avulsos, o arquivo do poeta é composto por materiais de cariz bibliográfico. Desta evidência material se conclui que, apesar da publicação de apenas um pequeno livro e três folhetos em vida, Pessoa concebia uma ideia de livro e de conjunto de livros que condicionava e estruturava o seu modo de escrita. Esta ideia resulta no caso específico de Pessoa de um pensamento editorial que acompanhava a escrita da sua obra e encontra correspondência material nos escritos. Procurarei em seguida contextualizar e precisar as preocupações de Pessoa com a materialidade de um suporte, o livro, distinto daquele que afinal constitui o suporte preferencial da obra, os quase 30000 papéis que compõem o espólio à guarda da Biblioteca Nacional, ${ }^{2}$ analisando diversos testemunhos dessa dimensão bibliográfica da sua escrita. Estes testemunhos serão relacionados com uma ideia de livro e de coleção de livros, que foi objeto de análise de um ensaio por mim recentemente publicado (cf. Sepúlveda, 2013).

Importa situar Pessoa num contexto modernista que pode ser caraterizado a partir de uma atenção particular, e sem precedentes, concedida às propriedades formais dos suportes de escrita (cf. nomeadamente McGann, 1993 e Drucker, 1994 e 1995). Os estudos de Johanna Drucker sobre a experimentação tipográfica do Modernismo, que segundo a mesma floresceu principalmente entre o final do séc. XIX e os meados de 1920, associada a correntes vanguardistas como o Futurismo, o Dadaísmo ou o Cubismo, insistem na atenção dada à materialidade como base de uma substância autónoma e autossuficiente, que implicaria uma noção de representação como equivalente ao estatuto de ser real (49-50). Independentemente de colocar o acento da sua pesquisa em obras que se assumem explicitamente como experimentalistas no campo tipográfico, como no caso das suas análises sobre o livro de artista (1995), Drucker aponta para uma abundância generalizada de elementos metacríticos nas obras de poetas modernistas, em particular no que diz respeito ao preenchimento da página e à apresentação gráfica e editorial do texto.

\footnotetext{
${ }^{1}$ No que concerne os vários sentidos possíveis a que o termo "arca" se refere, por metonímia, na tradição crítica, cf. Dionísio, 2008.

${ }^{2}$ Em 1988, as inventariadoras do espólio referiam-se a 27543 folhas (cf. Santos et al., 1988: 201), correspondentes ao conjunto comprado pelo Estado em finais de 1979, ao qual foram adicionados posteriormente outros documentos, decorrentes principalmente da aquisição pelo Estado de documentos que se encontravam com a família do poeta em 2008 , a que se seguiu a classificação do espólio como "tesouro nacional" em 2009. Estes e outros documentos adquiridos ou doados por particulares aproximam o arquivo hoje à guarda da Biblioteca Nacional dos 30000 papéis.
} 
Ainda que possam ser traçados paralelos pertinentes entre Mallarmé e Pessoa no que diz respeito a questões tipográficas e a uma ideia de livro projetada no futuro, ${ }^{3}$ a atenção do poeta português às dimensões bibliográficas e editoriais da página escrita não é acompanhada, salvo em casos excecionais como o de algumas das Odes de Álvaro de Campos, por um experimentalismo gráfico caraterístico do Simbolismo francês ou do Futurismo. No caso de Campos, a intensificação da experiência sensorial pelo recurso a interjeições, onomatopeias e a uma disposição gráfica do poema que destaca certos trechos, aumentando por exemplo o tamanho da letra, tem que ver com um legado do Futurismo que assume aí particular importância. $\mathrm{O}$ mesmo tipo de abordagem não é extensível à restante obra, onde o tratamento dos textos por Pessoa está principalmente relacionado com a sua codificação bibliográfica, ou seja, com elementos que indicam que estes foram escritos com o propósito de serem integrados num livro. O livro não é para Pessoa um modo transparente de expressão, pensado em moldes românticos, mas uma forma com especificidades, sobre a qual o poeta reflete e em torno de cujas possibilidades constrói uma obra, ainda que esta permaneça em grande parte por publicar.

Em Black Riders, The Visible Language of Modernism, Jerome McGann (1993) defende o argumento de que a poesia modernista escrita em língua inglesa no séc. XX é "função" e "expressão direta" de um renascimento da imprensa em finais do séc. XIX (xi-xiv). O crítico situa as obras de Yeats, Pound, Stein ou Williams no contexto de uma explosão da impressão de livros em finais do séc. XIX, tanto no que diz respeito a uma impressão comercial de amplo alcance como a pequenas tiragens caraterizadas por um cuidado particular com a apresentação do livro e produzidas em pequenas editoras, que surgem como reação a uma generalização da impressão de livros. Partindo deste contexto histórico, McGann analisa o modo como nestes autores são decisivas as preocupações com a apresentação gráfica da obra no livro e como esta é escrita, tal como acontece em Pessoa, tendo em vista a página impressa do livro enquanto codex.

$O$ facto de analisar autores que não se assumem explicitamente como experimentalistas no campo do livro e do grafismo da página reforça o seu argumento de que a ideia de edição da obra em livro é constitutiva da escrita modernista em termos genéricos, excedendo focos artísticos pontuais. Segundo McGann, em causa está uma produção autoconsciente e reflexiva do texto, que lhe atribui uma moldura ou armação (frame), colocando em causa uma ideia romântica de transmissão direta da interioridade do eu ou da mente (21). Esta ideia dá lugar a uma construção autoconsciente da obra e do livro, que McGann formula em termos que não são de todo estranhos a

${ }^{3}$ A respeito de questões tipográficas em Mallarmé cf. Drucker, 1994: 50-60. Sobre paralelos entre uma ideia de livro em Mallarmé e Pessoa cf. Buescu, 2003 e Sepúlveda, 2013: 193-206. 
Pessoa, enquanto "apresentação teatral" e de um suposto "diálogo da mente consigo mesma": "In a self-consciously constructed book, the romantic scene discloses itself as a rhetorical display, not the dialogue of the mind with itself, but the theatrical presentation of such a dialogue" (ibid.). ${ }^{4}$

Nos casos de Gertrude Stein e de Emily Dickinson, o autor mostra como uma recusa de publicação da obra ou a sua publicação apenas parcial, em pequenas editoras e revistas de vanguarda, não implica um desinteresse no formato do livro (19-41). Pelo contrário, e à semelhança de Pessoa, a recusa de uma publicação imediata e de larga tiragem pode coexistir com uma atenção particular concedida a elementos bibliográficos e editoriais da página escrita.

\section{Livros por escrever: elementos bibliográficos do arquivo}

Vários elementos da escrita de Pessoa revelam a sua dimensão bibliográfica e editorial, estando unidos por um traço comum, o de projetarem no futuro uma concretização da obra distinta da que se encontra na folha conservada no arquivo. Esta projeção tem por base a diferença entre uma concretização pontual, publicada ou não, e uma ideia de obra enquanto totalidade orgânica, que a associa ao livro e a uma coleção de livros por concretizar.

Numa procura de sistematização, poder-se-ia distinguir diversos tipos de codificação bibliográfica do texto em Pessoa, isto é, da inserção de elementos que o associam ao formato do livro. Note-se que estes elementos estão presentes exclusivamente em documentos do arquivo, ou seja, não se encontram em testemunhos de publicações em vida. Ao publicar os textos, Pessoa libertava-os de marcas de fragmentariedade, que os pudessem associar a versões distintas da que era publicada, ao livro ou a um todo que excedesse a parte concretizada. ${ }^{5}$ Sendo extremamente seletivo e cuidadoso em cada publicação, o texto publicado apresenta um estádio aparentemente final, só colocado em causa tanto por revisões posteriores em exemplares de mão, como por notas, comentários ou projetos editoriais que concebiam posteriormente uma edição do texto distinta da publicada.

Isto não é menos verdadeiro quando existe uma publicação em folheto ou livro, concebendo Pessoa nestes casos uma revisão e eventual republicação. Um primeiro tipo de elemento bibliográfico seria pois a inserção de anotações, emendas e variantes em textos já publicados, com vista ao estabelecimento de um novo texto e recusando o caráter definitivo de uma publicação. Numa nota escrita no último ano de vida, Pessoa

4 "Num livro construído de forma autoconsciente, a cena romântica revela-se como dispositivo retórico, não o diálogo da mente consigo mesma, mas a apresentação teatral desse diálogo." (trad. da minha responsabilidade).

5 A respeito do estatuto do fragmento na obra de Pessoa cf. Gusmão, 2003; Martins, 2003; Patrício, 2012: 163-181 e Sepúlveda, 2013: 275-302. 
expressa a ideia de que todos os "livros ou folhetos" que publicara, e que considera "válidos", necessitariam de uma revisão:

Obras que tem publicado: A obra está essencialmente dispersa, por emquanto, por varias revistas e publicações occasionaes. O que, de livros ou folhetos, considera como válido, é o seguinte: "35 Sonnets" (em inglez), 1918; "English Poems I-II" e "English Poems III" (em inglez tambem), 1922, e o livro "Mensagem", 1934, premiado pelo Secretariado de Propaganda Nacional, na categoria "Poema". O folheto "O Interregno", publicado em 1928, e constituindo uma defeza da Dictadura Militar em Portugal, deve ser considerado como não existente. Ha que rever tudo isso e talvez que repudiar muito. (Pessoa, 2011: 142-143)

Considerando apenas Mensagem um livro e tanto as diversas edições dos Poemas Ingleses como O Interregno folhetos, pode surpreender o apontamento final de que todas estas publicações necessitariam de revisão e de que muito do que contém mereceria repúdio. Nesta mesma linha, um esboço de uma nota de teor semelhante, autobiográfico e bibliográfico, elaborado como resposta a um questionário e datada de 14/10/1931, refere-se a "todas" as suas "obras" como "virtuaes", incluindo "semi-obras em revistas e trez folhetos em verso inglez": "São todas virtuaes, as principaes e as outras. Publicadas ha varias semi-obras em revistas e trez folhetos em verso inglez — “35 Sonnets" (Lisboa, 1918), "English Poems, I-II" e "English Poems, III” (simultaneamente, Lisboa, 1922).” (Sepúlveda, 2013: 386-387).

Em 1918, Pessoa publica dois pequenos livros, relegados pelo próprio ao estatuto de "folhetos", os conjuntos de poemas Antinous e 35 Sonnets. O primeiro foi republicado em livro em 1921, ${ }^{6}$ incluindo ainda um segundo conjunto, Inscriptions, e que, nas palavras do autor, publicadas no verso da folha de rosto da nova edição, sendo "essencialmente diferente" deveria "anular e suplantar" a anterior versão, "muito imperfeita": "An early and very imperfect draft was published in 1918. The present one is meant to annul and supersede that, from which it is essentially different." "7 Estas considerações são justificativas das inúmeras modificações introduzidas no texto. $O$ segundo folheto, "35 Sonnets", foi profusamente anotado e emendado por Pessoa, através de pelo menos duas campanhas de anotações sobre dois exemplares de mão conservados no arquivo (cf. Dionísio, 1993).

${ }^{6}$ Esta edição pode ter chegado a circular apenas em 1922, como indica a nota acima citada; a este respeito cf. Dionísio, 1993: 31.

7 “Um primeiro esboço, muito imperfeito, foi publicado em 1918. A presente versão vem anular e suplantar a anterior, da qual é essencialmente diferente." (trad. da minha responsabilidade). Em carta a João Gaspar Simões de Novembro de 1930, Pessoa escreve sobre Antinous, corrigindo o lapso da Tábua Bibliográfica, que "esse poema foi reconstruido e aperfeiçoado, dando aquelle que abre os "English Poems" posteriormente publicados" (Pessoa, 1998: 137). 
Este tipo de revisões de textos já publicados é frequente, o mesmo se passando relativamente aos poemas de Caeiro publicados na revista Athena e a Mensagem, ambos partindo de exemplares conservados pelo poeta, hoje à guarda da Casa Fernando Pessoa. ${ }^{8}$ Entre as publicações em livro consideradas válidas, $O$ Interregno é considerado pelo poeta na primeira nota citada "não existente", por apresentar uma posição política entretanto abandonada, não havendo por isso lugar a reformulações ou campanhas de revisão.

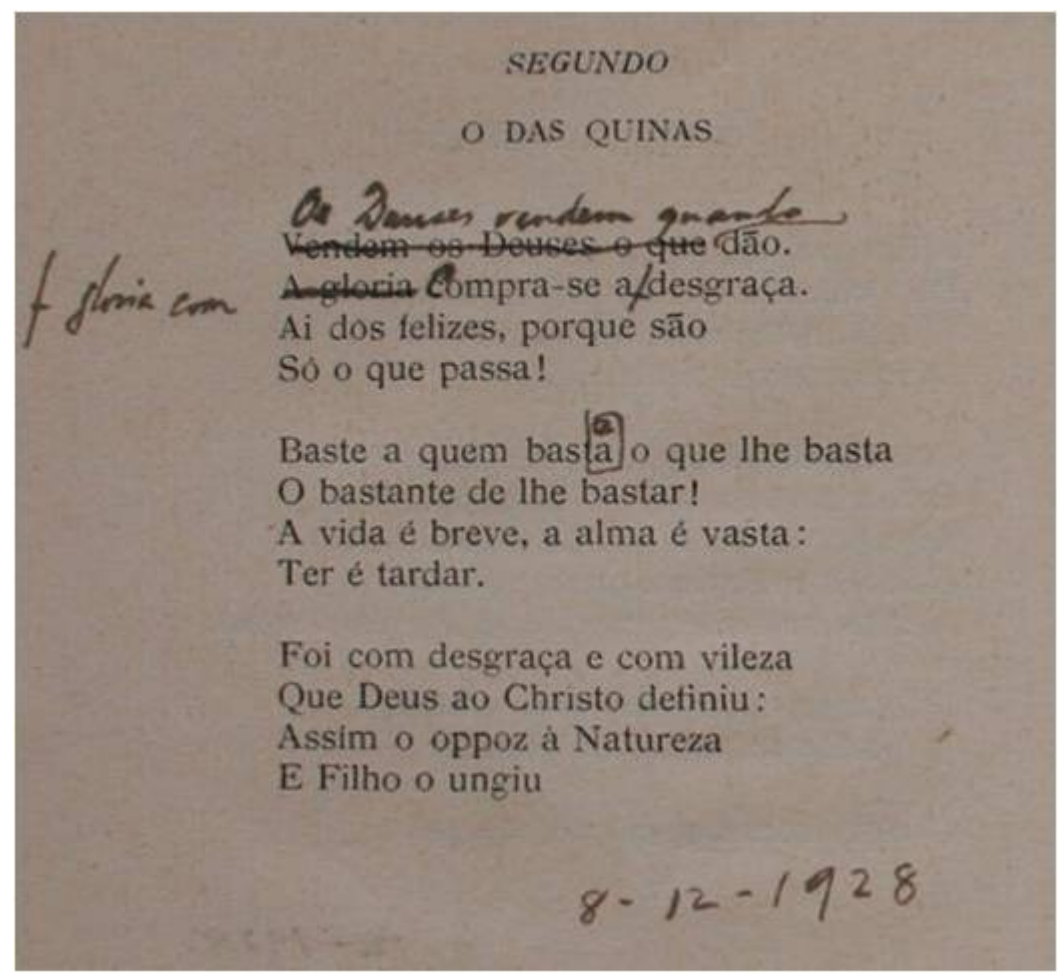

Figura 2. Mensagem, Lisboa: Parceria António Maria Pereira, 1934 (CFP 8-435).

No exemplar de Mensagem, Pessoa introduz as datas de redação de alguns poemas, assim como emendas pontuais mas significativas de alguns versos. Esta campanha de revisão não foi tão abundante em modificações como no caso da dupla campanha a que foram submetidos os 35 Sonnets, mas é de foro semelhante, incidindo sobre o mesmo tipo de elementos. Trata-se sobretudo de emendas de foro sintático e semântico ("Wenter Os Deuses vendem quando dão | A gloria Ceompra-se a gloria com a desgraça", cf. Figura 2; "X — And knows it eolded cold away from its solidness.”; cf. Figura 3), mas há também lugar à introdução de variantes sobre as quais não recai uma escolha,

8 Cf. os exemplares CFP 0-28 e CFP 8-435, consultáveis em http://casafernandopessoa.cm-lisboa.pt 
permanecendo uma hesitação a respeito de uma versão final ("Doth buy fetch eke our perplexed thinking, for we get."; cf. Figura 3). Em qualquer dos casos está implícita a ideia expressa por Pessoa na nota de que nenhuma das publicações é definitiva, devendo ser submetida a revisões e parcialmente repudiada.

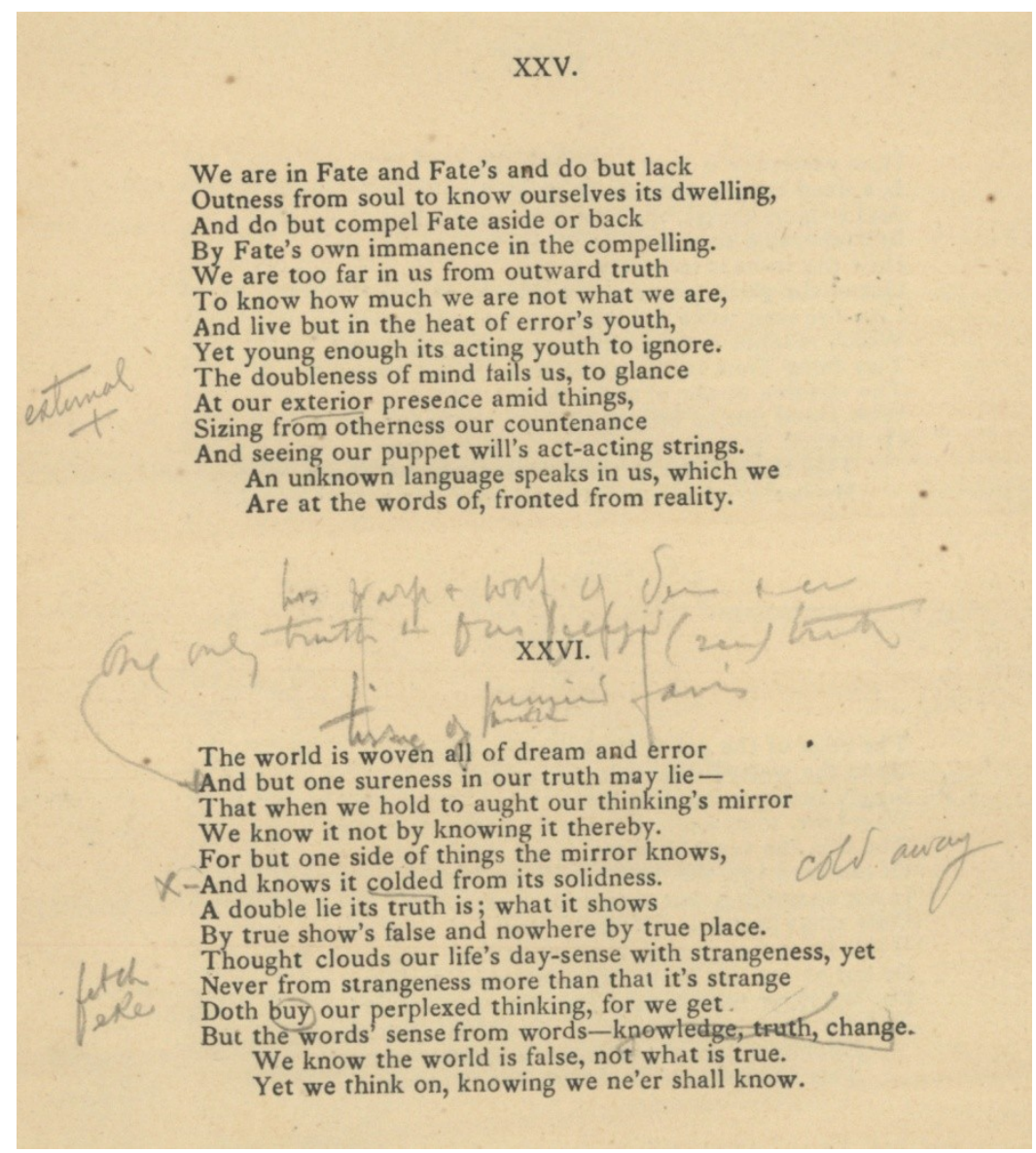

Figura 3. 35 Sonnets, Lisboa: Monteiro \& Co., 1918 (BNP 98-7r).

O arquivo pessoano está repleto de textos inacabados, e entre as marcas desse inacabamento destaca-se a presença de anotações, emendas e variantes. Estas marcas remetem para um texto materialmente inexistente, mas que o editor póstumo se vê na necessidade de compor a partir das indicações deixadas. As metodologias de edição divergem quanto aos elementos que privilegiam, com vista ao estabelecimento de um texto que diverge necessariamente do material que se encontra arquivado. ${ }^{9}$ Embora possam

${ }^{9}$ A respeito destas diferentes metodologias cf. Martins, 2011; Castro, 2013 e Duarte, 1988. 
existir edições que se centram numa transposição tipográfica e diplomática da página, uma edição nunca poderá conter todos os elementos que a página escrita apresenta.

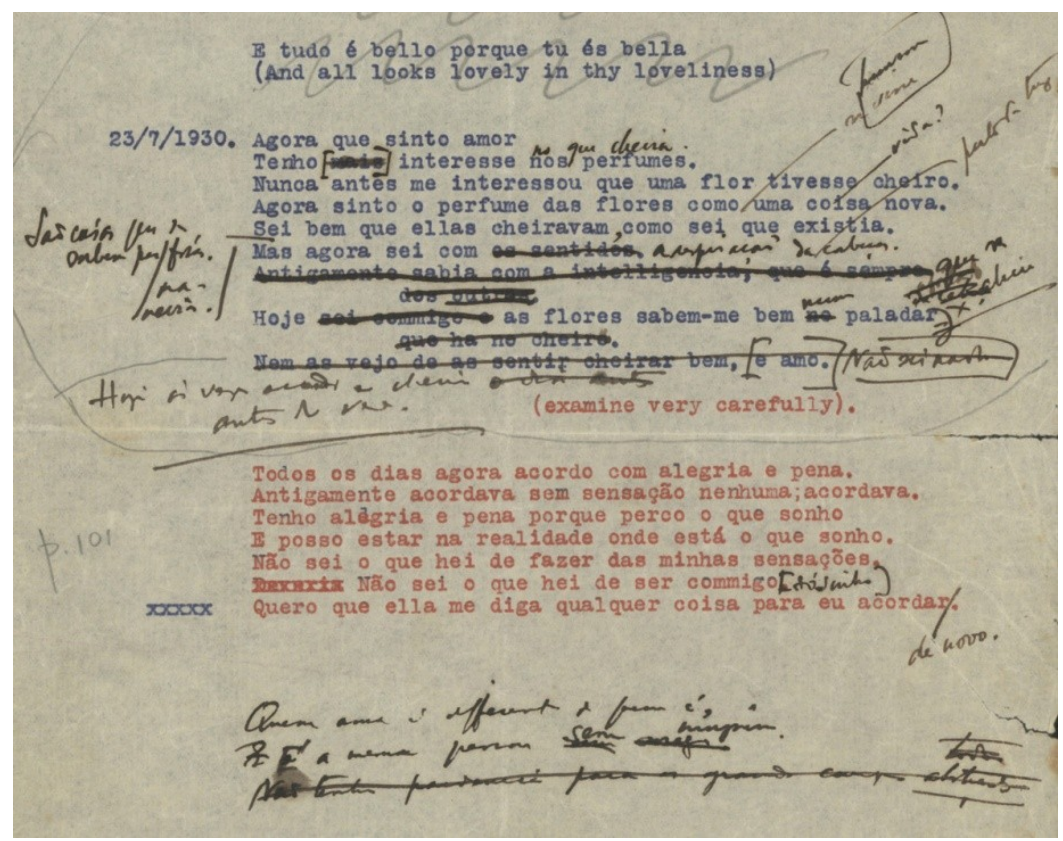

Figura 4. BNP 67-67r

Para além de variantes sobre as quais frequentemente não recai uma escolha, os textos apresentam anotações de tipo editorial, em português ou inglês, indicando nomeadamente uma necessidade de exame posterior do texto - "(examine very carefully)", como se lê num poema de Alberto Caeiro destinado ao conjunto $O$ Pastor Amoroso, que apresenta várias campanhas de revisão manuscrita sobre uma primeira versão datilografada, cf. Figura 4 - ou incluindo uma data ou uma epígrafe (no mesmo texto encontra-se uma epígrafe posteriormente riscada, que Pessoa traduz do inglês de versos do soneto Love's Blindness, de Alfred Austin: "E tudo é bello porque tu és bella (And all looks lovely in thy loveliness)." 10 É curioso como a mesma tinta com que Pessoa escreve aquele que a maioria dos editores escolheu como o poema seguinte do ciclo, na mesma página, lhe serve para deixar explícita uma necessidade de exame do primeiro. A diferença que Fernando Cabral Martins aponta entre o "crítico" e o "autor" em Pessoa é um importante ponto de partida para entender as duas dimensões presentes no texto, ainda que no caso de Pessoa indissociáveis e por vezes difíceis de destrinçar (cf. Martins, 2012: 100). O crítico seria aquele que anota o texto 
com vista à sua modificação editorial e a sua transposição para um novo suporte, indicando a necessidade de o reexaminar ou de introduzir um exemplo, uma nota ou uma epígrafe em falta. Enquanto no exemplo de "O Pastor Amoroso" surge uma epígrafe posteriormente riscada, no caso do poema "Liberdade" a sua segunda versão, posterior a uma primeira com data de 16/3/1935, indica que "(falta uma citação de Seneca)" que possa exercer a função de epígrafe do poema (cf. Figura 5 e a nota de Luís Prista a respeito dos dois testemunhos deste poema em Pessoa, 2000a: 440-441).

Entre os elementos com funções editoriais e bibliográficas destaca-se, no entanto, um elemento fundamental e que une a codificação bibliográfica da página e a conceção estética da obra. Trata-se da função exercida pelo nome de autor enquanto categoria unificadora, na sua dupla dimensão editorial e estética. Ao colocar este nome na posição habitualmente reservada ao título do texto, Pessoa delimita-o enquanto pertencente a determinada parte da obra, a que corresponde uma figura. Sublinhe-se como uma hesitação que por vezes surge neste tipo de atribuição acontece não só entre dois nomes distintos como entre nome de autor e título de obra, mostrando como ambos exercem aqui uma função semelhante, de delimitação de uma obra de um ponto de vista tanto estético quanto editorial. Como se lê na primeira folha catalogada no espólio de Pessoa, habitualmente incluída nas edições do Livro do Desassossego, "A[lvaro] de C[ampos] (?) ou L[ivro] do D[esassossego] (ou outra cousa qualquer)" (cf. Figura 6). A dúvida mantida quanto ao posicionamento do texto alberga possibilidades de sentido muito distintas, ao conceber a ideia de uma atribuição a Campos ou ao Livro. A naturalidade com que a crítica muitas vezes se refere a determinado texto como sendo de Campos, Caeiro, ou do Livro contrasta com as constantes hesitações assinaladas nos testemunhos ou a falta de atribuição de muitos textos. 


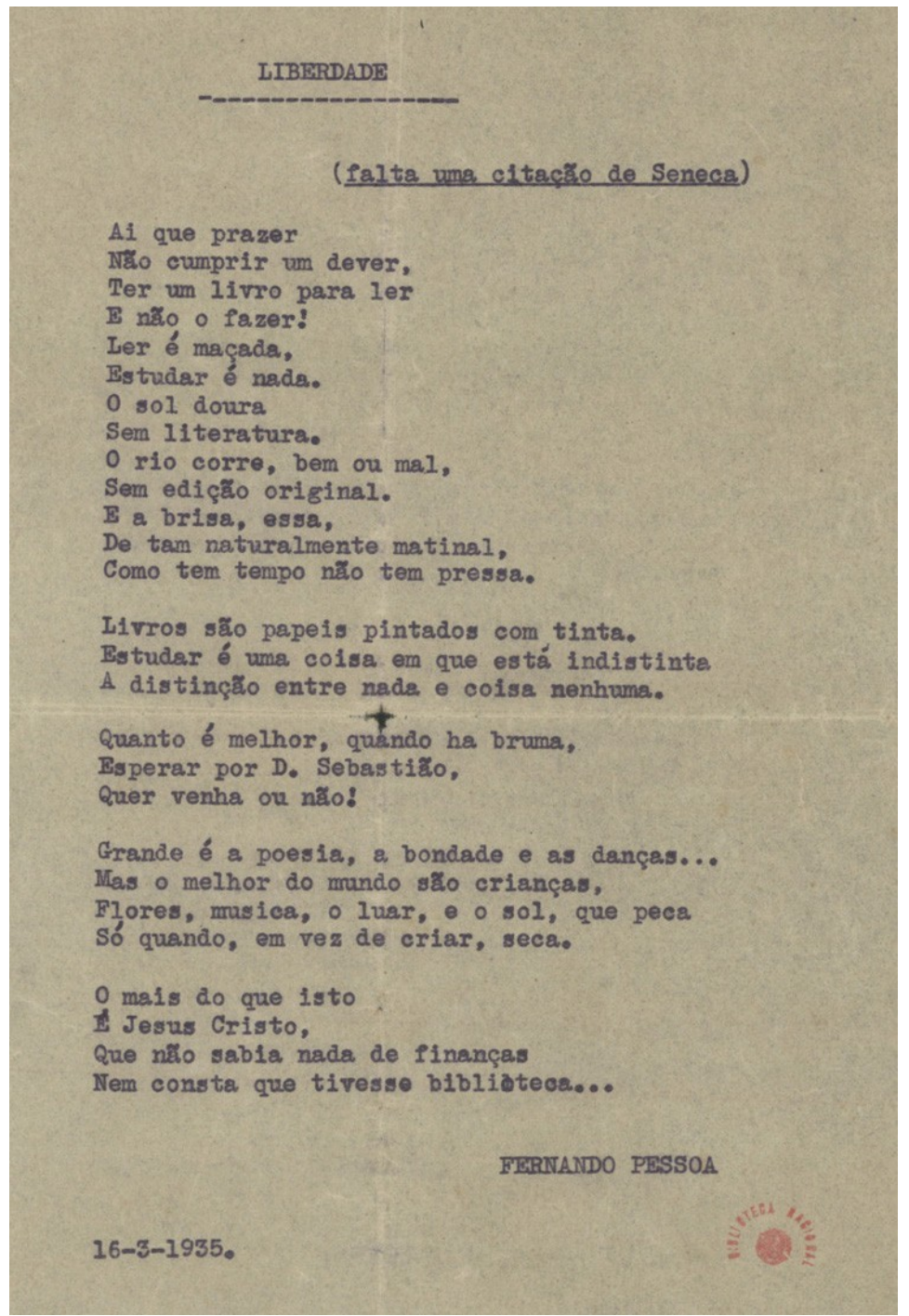

Figura 5. BNP $118-55^{\mathrm{r}}$.

A. de C. (?)

ou L. do D. (ou outra cousa qual quer)

A arte é um esquivar-se a agir, ou a viver. A arte 6 a expressão intellectual da emoção, distincta da vida, que e a expressão volitiva da emoção. O que não bemos, ou não ousamos, ou não conseguimos, podemos possuil-o em sonho, e é com esse sonho que fazemos arte. Outras vezes a emoção' es a tal ponto forte que, embora reduzida a acção, a acção, a que se reduziu, não a satisfaz; com a emoção que sobra, que ficou inexpressa na vida, se forma a obra de arte. Assim, ha dois typos de artista: o que exprime o que não tem, e que exprime o que sobrou do que teve.

Figura 6. BNP $1-1^{\mathrm{r}}$. 
O nome de autor refere em Pessoa metonimicamente a própria obra, e a escolha do nome é, como mostraram António M. Feijó e Richard Zenith, motivada pela sua adequação à obra. ${ }^{11} \mathrm{Na}$ linha do que defende Michel Foucault, importa distinguir a função exercida por um nome de autor da pessoa ou figura para a qual remete esse mesmo nome. Como este sublinha, o nome de autor transcende uma função meramente referencial e designa um objeto diferente daquele a que se refere o nome próprio. $\mathrm{O}$ seu argumento, bem conhecido, é o de que este nome não é simplesmente um "elemento de um discurso", mas "exerce relativamente aos discursos um certo papel: assegura uma função classificativa [...] permite reagrupar um certo número de textos, delimitá-los, selecioná-los, opô-los a outros textos". ${ }^{12}$ Esta função classificativa é independente da sua referência a uma pessoa ou figura, real ou não. Ao transportar esta relação para o domínio da ficção, Pessoa tem em vista este tipo de funcionamento do nome, que designa e delimita uma obra de um ponto de vista editorial e bibliográfico, devendo esta função ser distinguida de uma referência à figura que o nome também designa e cuja espessura depende também de uma relação com a obra. Neste sentido, uma dúvida na atribuição autoral coincide com uma hesitação quanto à pertença de determinado texto a uma obra. Não surpreende que um poema que começa com o verso "Num dia brancamente nublado entristeço quase a medo" e prossegue num tom de meditação metafísica sobre a doença e a impossibilidade de alcançar a perfeição seja de atribuição duvidosa a Caeiro, ainda que os versos estilisticamente só possam pertencer à obra e ao livro do mestre. O desvio de conteúdo justifica aqui a dúvida marcada na atribuição que encabeça o poema: "Caeiro (?)" (Figura 7).

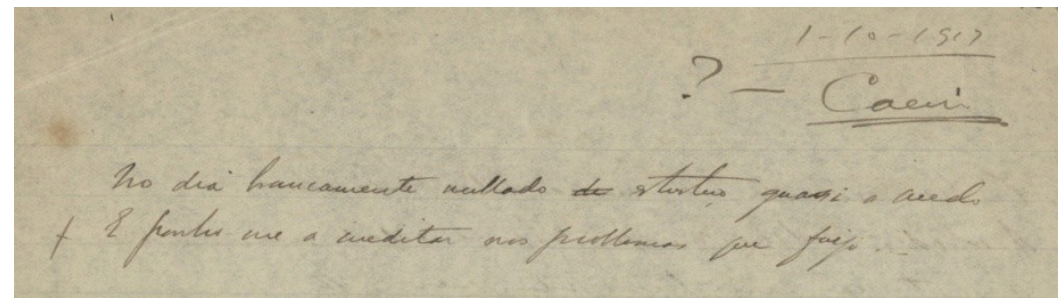

Figura 7. BNP 16A-6r.

11 Feijó sublinha uma "motivação forte" na escolha dos nomes, defendendo nomeadamente que Caeiro seria "uma variante de "caieiro", que significa "caiador" (188). Seguindo a mesma ideia, Richard Zenith aponta para outra possível origem motivada do nome Caeiro: "O nome Caeiro é, por assim dizer, Carneiro sem a carne, para um pastor cujos carneiros foram espiritualizados em pensamentos [...].” (230).

12 Sigo aqui a tradução de António Fernando Cascais e Edmundo Cordeiro (cf. Foucault, 1992: 44-45 e também 1994: 798). 


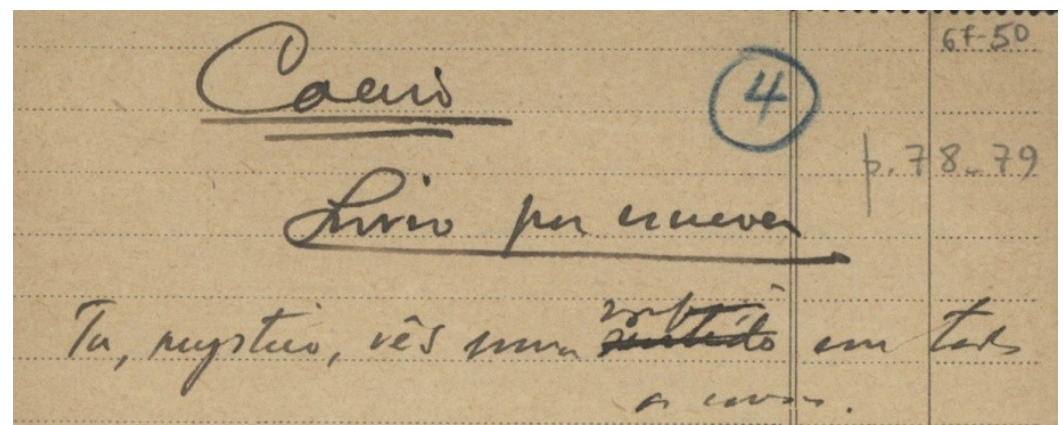

Figura 8. BNP $67-50^{\mathrm{r}}$.

Caeiro, antes de designar uma figura, designa uma obra e, neste como nos casos das principais obras de Pessoa, um livro, que corresponderia à reunião dos textos e a sua publicação neste formato. "O livro de Caeiro", como se lê em diversas passagens que o comentam, criticam ou prefaciam, ${ }^{13}$ está sempre "por escrever", o próprio Caeiro é este "livro por escrever", para que os seus poemas remetem (cf. Figura 8). A relação entre a ideia de livro e de pessoa, que será esboçada em seguida, justifica esta coincidência entre obra, livro e figura. A ficcionalização da categoria de autor, prefaciador e tradutor, assim como das próprias circunstâncias de edição e publicação do livro, marcam um tratamento metacrítico, autoconsciente e reflexivo do texto e da sua materialidade que contrasta com qualquer noção romântica de expressão direta e transparente. Prevendo uma edição dos "Poemas Completos de Alberto Caeiro" "editados e prefaciados por Ricardo Reis" em "tiragem limitada a 100 exemplares, fóra do Mercado", entre outros inúmeros projetos de edição do livro (cf. a este respeito Sepúlveda, 2013: I e III), Pessoa integra as reflexões sobre o livro na sua conceção dramática da obra enquanto diálogo de personagens, que comentam, criticam e também editam as obras uns dos outros.

${ }^{13}$ Cf. nomeadamente Pessoa, 1994: 184, 213 e 262. 


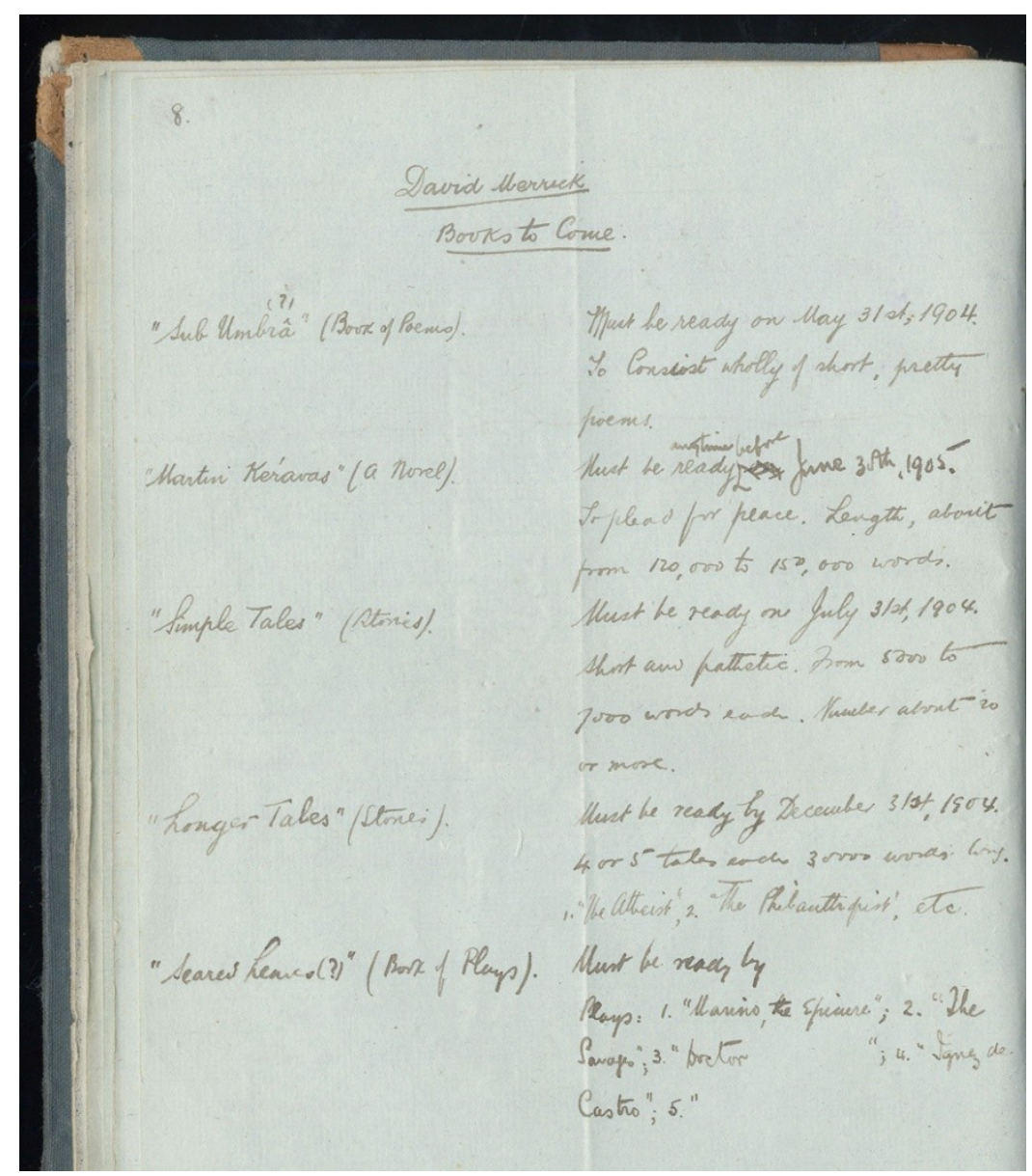

Figura 9. BNP 153-8v.

A função editorial da categoria de autor, que não só classifica e delimita a obra como a relaciona com uma configuração editorial da mesma, que pode ser a do formato livro ou em alguns casos uma revista, é particularmente evidente nas inúmeras listas de planeamento editorial que alberga o arquivo pessoano. Estas listas estruturam determinada obra ou listam um conjunto de obras a editar e publicar, conferindo-lhes um sentido de conjunto que vai além do propósito prático de publicação. Nesta medida, as listas possuem uma dimensão literária, no sentido que lhe atribui Robert E. Belknap no seu estudo sobre a lista em literatura, ao considerar que as listas literárias são geradoras de um sentido que vai além da simples referencialidade, comunicam informações relevantes em termos literários e se relacionam diretamente com a obra na qual estão inseridas. ${ }^{14}$

${ }^{14}$ Cf. Belknap, 2004: 1-19, assim como Eco, 2009: 113-118. 
O nome de autor surge nestas listas como categoria estruturante e princípio unificador de projetos em muitos casos pré-existentes. ${ }^{15}$ Assim acontece numa lista elaborada por um Pessoa muito jovem, em 1904, que atribui ao nome "David Merrick" uma série de livros por vir ("Books to come") e cujos títulos correspondem, na sua maior parte, a pequenos textos fragmentários existentes no mesmo caderno em que se encontra a lista (cf. Figura 9). O que a lista portanto faz é organizar textos já existentes unificando-os em torno de um nome, que remete para uma figura. $\mathrm{O}$ facto de nenhum destes livros ter chegado sequer a ser preparado para publicação contrasta com o caráter incrivelmente minucioso das descrições de cada um dos projetos e do modo como os livros deveriam ser preparados e apresentados. Prevendo para cada um deles, à exceção do último, uma data em que deveriam estar prontos ("Must be ready on May 31st, 1904 | anytime before June 3rd, 1905 | on July 31st, 1904 | by December 31st, 1904 | by 口"), a lista inclui ainda indicações sobre o conteúdo literário do livro ("Book of Poems" | "To consist wholly of short, pretty poems"; "A Novel” | "To plead for peace"; "Stories" | "Short and pathetic" | "4 or 5 tales each"; "Book of Plays" | "Plays") e a sua extensão ("120000 to 150000 words" | “5000 to 7000 words each" | "each 30000 words long”). Ao contrário do que o editor Jacques Scherer afirma a respeito dos manuscritos de Mallarmé preparatórios do seu Livre, a presença de inúmeras notas de tipo editorial, esquemas e projetos não manifesta um "estado mórbido bem conhecido e perfeitamente catalogado" (Scherer, 1977: 314) mas, em ambos os autores, a presença de uma projeção da obra que a concebe como concretizada num suporte distinto daquele em que se encontra. Esta projeção confere aos respetivos títulos um sentido de completude e de conjunto que não permite considerá-los apenas trechos isolados e fragmentários.

${ }^{15}$ Cf. a este respeito o caso de Thomas Crosse, analisado em Sepúlveda e Uribe, 2013, e de Alberto Caeiro, em Castro, 2013: I e Sepúlveda, 2013: I e III. 


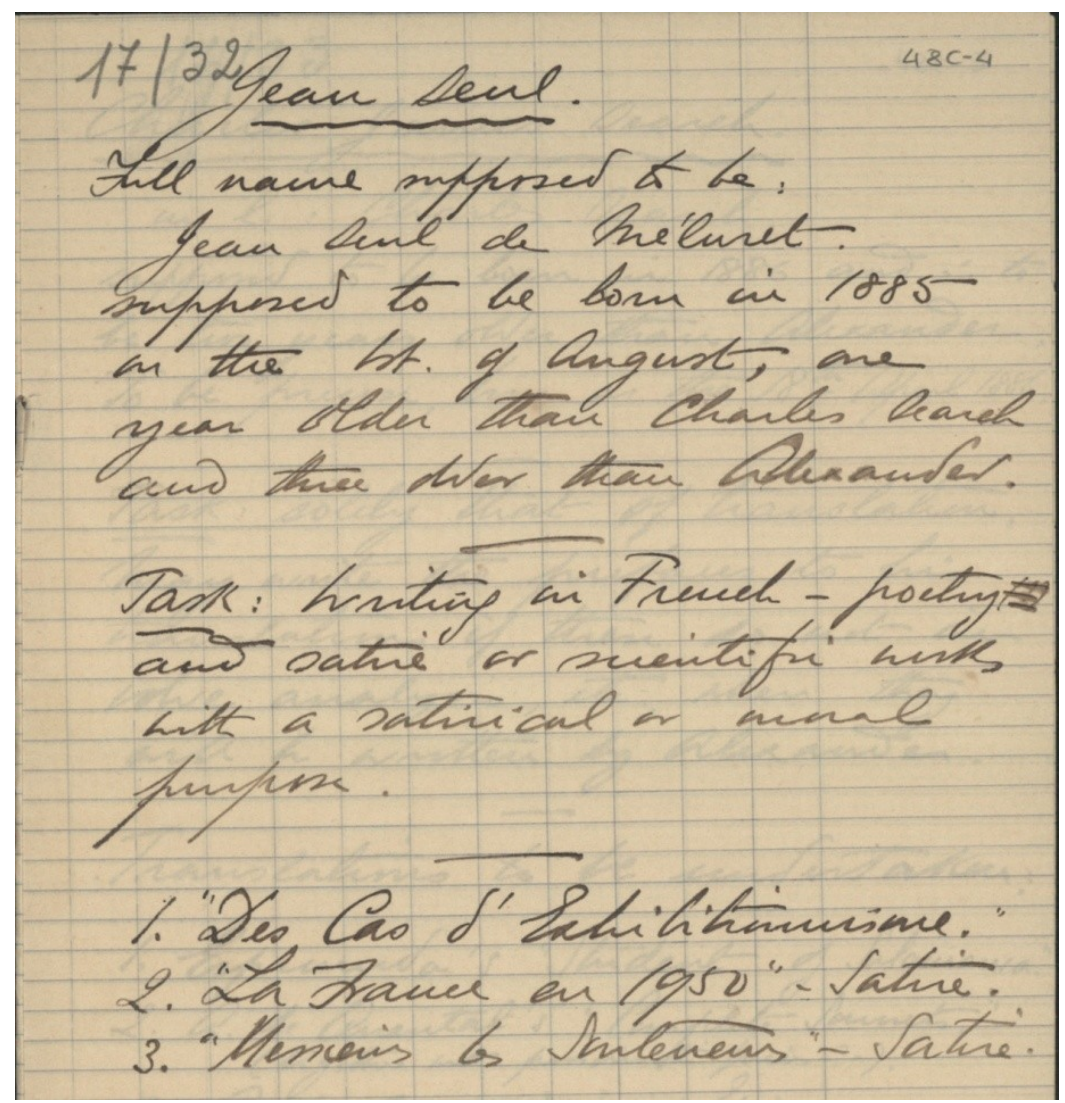

Figura 10. BNP 48C-4r.

Em meados de 1908, Pessoa concebe um projeto de livro que é simultaneamente um caderno de encargos, segundo o seu próprio título, "The Transformation Book or Book of Tasks". ${ }^{16}$ Ficaram deste projeto páginas em que são apresentados quatro autores ficcionais, incluindo algumas notas biográficas e atribuições de tarefas, tarefas estas que consistem na escrita ou tradução de obras. Trata-se de um projeto que nasce da interseção de um propósito editorial, de organização em livro de obras pré-existentes, com a elaboração de biografias das figuras a quem estas obras são atribuídas. Como nos casos de Alexander Search, Charles James Search, irmão de Alexander, e Pantaleão, Jean Seul é aqui apresentado como figura que vem assumir a autoria de textos previamente existentes e que constam de listas de projetos anteriores (cf. Figura 10). Este dado é sublinhado por Rita Patrício e Jerónimo Pizarro, na sua introdução à edição das obras de Jean Seul: "Como pretendemos mostrar, estes três escritos antecedem, pelo menos em parte, a criação de Jean Seul” (Patrício e Pizarro, 2006: 9). A figura de Jean Seul ("Full

${ }^{16}$ Cf. BNP 48C-1 a 5r; Pessoa, 2012: 361-364 e sobre a datação Patrício e Pizarro, 2006: 10-11. 
name supposed to be: Jean Seul de Méluret") permite reunir três textos de índole sociológica e satírica, escritos em francês, que o levam a assumir enquanto figura o papel de autor de "sátiras ou escritos científicos com um propósito satírico ou moral". Os três títulos, "Des Cas d' Exhibitionisme", "La France en 1950" e "Messieurs les Souteneurs", correspondem precisamente aos textos reunidos na edição das Obras de Jean Seul de Méluret (Pessoa, 2006). Correspondendo a uma organização de conjunto da obra que integra boa parte dos principais projetos em que Pessoa trabalhava na altura, principalmente em língua inglesa, trata-se pela sua abrangência de uma organização comparável ao que mais tarde se encontra a respeito da obra heterónima. Qualquer destas figuras é definida por contraste com as restantes, sendo Jean Seul um ano mais velho que Charles e três que Alexander ("one year older than Charles Search and three older than Alexander"), e a figura de Alexander Search identificada por meio da data de nascimento com a de Pessoa, ambos nascidos a 13 de Junho de 1888. Esta identificação permite a Search assumir uma posição de destaque face às restantes, ampliada pela noção de que assumiria todas as tarefas que excedessem o domínio dos outros ("Task: all not the province of the other three"; cf. Pessoa, 2012: 361).

Estes dois exemplos contrariam a ideia de que o interesse de Pessoa em publicar a sua obra, organizando-a em vários livros atribuídos a diferentes figuras autorais, seja um propósito tardio. Ambos revelam um tipo de pensamento editorial que tem, desde muito cedo, na criação de figuras autorais o seu princípio estruturante. Ao longo da década de 1910, serão principalmente os projetos construídos em torno dos ismos, em particular o Neo-Paganismo, a determinar uma ideia de conjunto da obra, integrando numa mesma série obras atribuídas a Caeiro, Campos, Reis, Mora e Pessoa. Em finais dos anos 20 e inícios de 30, os títulos Ficções do Interlúdio e O Regresso dos Deuses surgem como designações alternativas de um conjunto de teor semelhante, centrado nas "obras heterónimas" de Caeiro, Reis e Campos, segundo a classificação introduzida por Pessoa na Tábua Bibliográfica de 1928 (cf. Pessoa, 2000: 404). É curioso verificar como a posição do Livro do Desassossego nestes projetos apresenta uma grande variação, alternando entre uma integração no conjunto ou a sua separação e variando ainda no que respeita à atribuição de autoria, a Pessoa, Vicente Guedes, ou, a partir de final dos anos 20, a Bernardo Soares (cf. Sepúlveda, 2013a). 


\section{Pessoas-livros: algumas conclusões}

Uma lista de projetos editoriais intitula-se "Aspectos" e, prevendo um "Prefacio geral", integra cinco livros, atribuídos a Alberto Caeiro ("O Guardador de Rebanhos", "e outros poemas e fragmentos”), Ricardo Reis (“Odes"), António Mora ("Alberto Caeiro e a renovação do paganismo"), Álvaro de Campos ("Arco de Triumpho", "Poemas") e Vicente Guedes ("Livro do Desasocego”) (cf. Figura 11). Deste prefácio existem vários esboços, alguns deles escritos no mesmo suporte da lista. O conjunto de títulos remete para projetos da segunda metade da década de 1910, que surgem, com pequenas variações, noutras listas deste período. A referência no texto do prefácio a uma ideia de publicação de uma série dedicada ao "neo-paganismo portuguez, com varios authores, todos differentes, a collaborar nelle e a dilatal-o" (Pessoa, 2010: 451), como ideia anterior e entretanto abandonada, leva a situar Aspetos como posterior a um conjunto de projetos relacionados com o Neo-Paganismo, elaborados entre 1915 e 1918. O facto biográfico de Ricardo Reis se encontrar, segundo a descrição, "na America”, pode aproximar também o texto de inícios da década de $1920 .{ }^{17}$

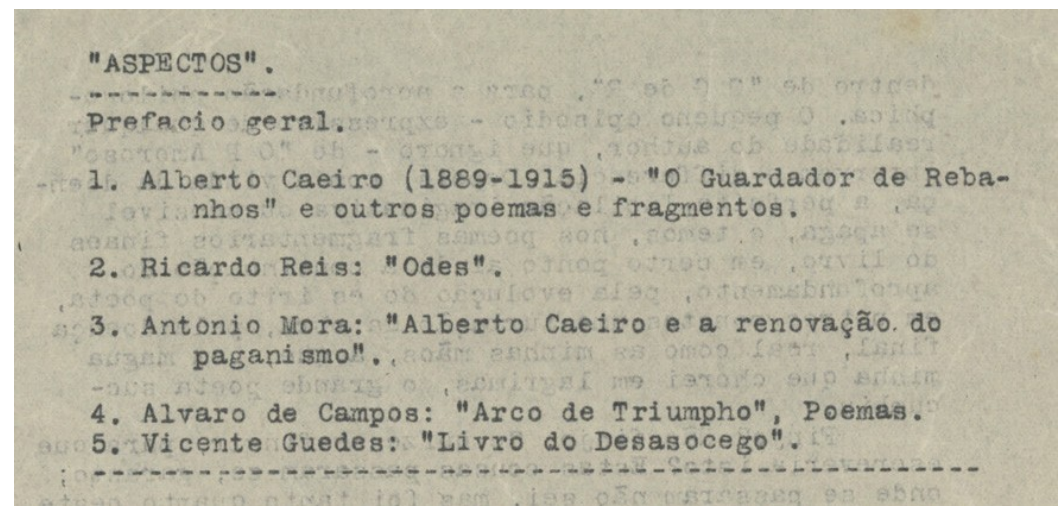

Figura 11. BNP 48C-29r.

Lê-se nestes esboços de prefácio que se inicia com estes cinco livros a "publicação" de uma "serie, ou collecção, de livros", que seria também uma coleção de "pessoas-livros" (446-447). O conceito pessoas-livros, aqui

17 Com base na proximidade desta lista com projetos da segunda metade da década de 1910 e na referência ao Neo-Paganismo, Teresa Sobral Cunha propõe a data conjetural de 1917 (cf. Pessoa, 1994: 321) e Jerónimo Pizarro a de 1918 (cf. Pessoa, 2010: 965). Fernando Cabral Martins e Richard Zenith indicam "1920?" como possível data, baseando-se neste facto biográfico de Ricardo Reis, lendo-se na célebre carta de 13 de Janeiro de 1935 a Adolfo Casais Monteiro que este "vive no Brasil desde 1919" (cf. Pessoa, 1998: 257). Note-se ainda como a referência a Vicente Guedes e ao Livro do Desassossego parece ter sido inserida posteriormente a uma primeira redação da lista, o que pode estar relacionado com a referida hesitação e variação quanto à posição do Livro no conjunto da obra. 
introduzido sem explicitação, torna-se claro se tivermos em conta o modo como é descrita programaticamente esta coleção de livros, que tem por base a ideia de "escrever estes 'aspectos' da realidade, totalizados em pessoas que os tivessem" (447). O termo "aspectos" possui um sentido astrológico bem conhecido de Pessoa, significando uma relação espacial entre dois astros em virtude da qual estes exercem uma força ou acção comum. Trata-se pois de pensar o livro como expressão de uma realidade que é representada por uma pessoa e totalizada nessa mesma pessoa. A ideia de totalidade diz aqui respeito tanto à pessoa como ao livro, termos indissociáveis com vista a uma acção comum, a da expressão de um aspeto da realidade. Assim, "a cada personalidade mais demorada, que o author d'estes livros conseguiu viver dentro de si, elle deu uma indole expressiva, e fez d'essa personalidade um author, com um livro, ou livros", sendo "cada personalidade d'essas [...] perfeitamente una comsigo propria" (448-449). Estas personalidades das figuras de Caeiro, Reis, Mora, Campos e Guedes possuem "as idéas, as emoções, e a arte dos quaes, elle, o author real (ou porventura apparente, porque não sabemos o que seja a realidade), nada tem, salvo o ter sido, no escrevel-as, o medium de figuras que elle-proprio creou" (449).

Independentemente da referência a um autor real, as figuras autorais são descritas como distintas deste criador, simples medium das mesmas. Está aqui implícita uma ideia de livro e de coleção de livros que os associa à expressão de uma personalidade, à qual corresponde uma faceta, um aspeto da realidade. A ficcionalização da autoria não impede Pessoa de ter aqui em vista um conceito tradicional de livro enquanto expressão da interioridade e totalidade expressiva que se opõe ao fragmento. A metáfora da totalidade, segundo Blumenberg a mais constante, do ponto de vista histórico, entre as metáforas implicadas na noção de livro (cf. Blumenberg, 1981: 9-16), serve aqui a Pessoa para definir um projeto de obra que passa pela criação de "toda uma litteratura" (Pessoa, 2010: 451), em que as questões da autoria e da edição coincidem no modo metareflexivo como é pensado o livro. Contrastando com o permanente estádio deficitário que Pessoa atribui à sua obra, e que apresenta os elementos acima analisados, através dos quais a página fragmentária remete para uma realidade do livro que a excede, a conceção da obra como totalidade condiciona a sua escrita e molda necessariamente os papéis do arquivo.

A uma metafísica da totalidade expressiva corresponde a sua projetada inserção no suporte do livro e uma ideia de coleção que implica a reunião de diferentes índoles expressivas. As profusamente analisadas conceções pessoanas do Sensacionismo e do Neo-Paganismo, expressas em máximas como sentir ou "ser tudo, de todas as maneiras, porque a verdade não pode estar em faltar ainda alguma cousa" (Pessoa, 2011: 265) ou na crença de que "na eterna mentira de todos os deuses, só os deuses todos são verdade” (ibid.), que remetem para uma pluralidade de expressões do real, vêem-se justificadas nos propósitos bibliográficos e editoriais do poeta. Pessoa mantém na sua 
ideia de obra a ligação estreita entre sujeito e livro que herda do Romantismo, mas a um nível metarreflexivo, que passa pela ficcionalização da autoria e a sua utilização enquanto princípio editorial que classifica e delimita obras.

Inserindo-se num contexto modernista de atenção particular às dimensões bibliográficas da página escrita, Pessoa legou-nos uma obra principalmente contida num arquivo, cujo suporte, o papel, como na imagem da arca, remete para outra realidade, a do livro. Como nos casos de Gertrude Stein e de Emily Dickinson analisados por Jerome McGann, o facto de a obra se encontrar principalmente em papéis avulsos e ter sido apenas parcialmente publicada não implica uma falta de atenção a elementos tipográficos da página que remetem para o suporte do livro. A produção autoconsciente e reflexiva do texto a que se refere McGann neste contexto permite a Pessoa associar dimensões habitualmente distintas, a editorial e a estética, implicando na criação de figuras autorais preocupações editoriais. A própria revisão do texto em Pessoa, que em nenhum caso o poeta considerou estar concluída, apela à necessidade de pensar conjuntamente os planos estético e editorial. Como escreve a propósito do Livro do Desassossego, este exigiria, no final dos anos 20, uma nova "organização", baseada "numa escolha, rigida quanto possivel, dos trechos variadamente existentes", adaptando-os à "vera psychologia" de Bernardo Soares, "tal como agora surge" (Pessoa, 2010: 453), considerando alguns anos mais tarde que os Poemas Inconjuntos de Alberto Caeiro necessitariam de uma revisão "não só verbal mas psychologica" (Pessoa, 1998: 210).

Os livros por escrever de Pessoa estão testemunhados numa obra contida principalmente num arquivo de papéis, mas também em alguns livros que o poeta não considerou definitivos. Implicando a criação de figuras autorais como princípio distintivo e unificador da obra e do livro, o que habitualmente se designa como a heteronímia de Pessoa, numa substantivação que o próprio nunca utilizou e que oculta o seu emprego adjetival enquanto "categoria de obra" (Pessoa, 2000: 404), não pode ser pensada sem esta dimensão bibliográfica e editorial. $\mathrm{O}$ mesmo acontece no que se refere à conceção dramática da obra, o famoso "drama em gente" (idem: 405), que não é possível pensar sem tomar em consideração essa "apresentação teatral" do "diálogo da mente consigo mesma" no "livro construído de modo autoconsciente" de que falava McGann a respeito do Modernismo (cf. McGann, 1993: 21), ainda que destes livros só nos restem a disjecta membra a que se referia Carlyle. ${ }^{18} \mathrm{~A}$ definição conclusiva dos livros que comporiam toda uma literatura implicava que o mesmo acontecesse com as suas figuras, pessoas-livros em que, "onde ha uma obra disposta chronologicamente, como em

18 Cf. Pessoa, 2000: 492: "E assim, do que poderia ter sido, fica só o que é, — do poema, ou dos opera omnia, só o princípio e o fim de qualquer coisa perdida - disjecta membra que, como disse Carlyle, é o que fica de qualquer poeta, ou de qualquer homem." 
Caeiro e Alvaro de Campos, a evolução da pessoa moral e intellectual do author é perfeitamente definida" (Pessoa, 2010: 448).

\section{Referências}

\section{Edições da obra de Fernando Pessoa}

PESSOA, Fernando (1993). Mensagem. Poemas Esotéricos. Coord. de José Augusto Seabra. Edição Crítica. Madrid [etc.]: Colecção Arquivos. (1994). Poemas Completos de Alberto Caeiro. Ed. de Teresa Sobral Cunha. Lisboa: Editorial Presença. (1998). Cartas entre Fernando Pessoa e os directores da Presença. Edição e Estudo de Enrico Martines. Ed. Crítica de Fernando Pessoa. Estudos. Lisboa: Imprensa Nacional-Casa da Moeda. (2000). Crítica. Ensaios, Artigos, Entrevistas. Ed. de Fernando Cabral Martins. Obras de Fernando Pessoa. Lisboa: Assírio \& Alvim. (2000a). Poemas de Fernando Pessoa. 1934-1935. Ed. de Luís Prista.

Edição Crítica de Fernando Pessoa. Lisboa: Imprensa Nacional-Casa da Moeda.

(2001). Alberto Caeiro. Poesia. Ed. de Fernando Cabral Martins e Richard Zenith. Obras de Fernando Pessoa. Lisboa: Assírio \& Alvim. (2006). Obras de Jean Seul de Méluret. Edição e Estudo de Rita Patrício e Jerónimo Pizarro. Edição Crítica de Fernando Pessoa. Lisboa: Imprensa Nacional-Casa da Moeda (2009). Cadernos. Tomo I. Ed. de Jerónimo Pizarro. Edição Crítica de Fernando Pessoa. Lisboa: Imprensa Nacional-Casa da Moeda. (2010). Livro do Desasocego. Tomos I e II. Ed. de Jerónimo Pizarro. Edição Crítica de Fernando Pessoa. Lisboa: Imprensa Nacional-Casa da Moeda.

(2011). Sebastianismo e Quinto Império. Edição, introdução e notas de Jorge Uribe e Pedro Sepúlveda. Obras de Fernando Pessoa. Nova Série. Lisboa: Ática.

(2012). Teoria da Heteronimia. Ed. de Fernando Cabral Martins e Richard Zenith. Páginas de Fernando Pessoa. Lisboa: Assírio \& Alvim.

\section{Outras fontes da obra de Fernando Pessoa}

BNP: Espólio de Fernando Pessoa à guarda da Biblioteca Nacional de Portugal (Espólio 3).

CFP: Livros da Biblioteca Particular de Fernando Pessoa, à guarda da Casa Fernando Pessoa.

Espólio de Fernando Pessoa disponibilizado na Biblioteca Nacional Digital, junho de 2014, http://purl.pt/1000/1/.

Portal da Casa Fernando Pessoa, onde se encontram disponíveis para consulta os exemplares da sua Biblioteca Particular, junho de 2014, http://casafernandopessoa.cm-lisboa.pt. 


\section{Outras referências}

BELKNAP, Robert E. (2004). The List. The Uses and Pleasures of Cataloguing. New Haven: Yale University Press.

BLUMENBERG, Hans (1981). Die Lesbarkeit der Welt. Frankfurt am Main: Suhrkamp Verlag.

BUESCU, Helena Carvalhão (2003). "Des livres du futur et du passé: Pessoa et Mallarmé (avec passage par Calvino et Ortega).” Representações do Real na Modernidade - ACT 7. Org. de Helena Carvalhão Buescu e João Ferreira Duarte. Lisboa: Centro de Estudos Comparatistas, Colibri. 43-59.

CASTRO, Ivo (2013). Editar Pessoa. 2. a edição, aumentada. Lisboa: Imprensa Nacional-Casa da Moeda.

DIONÍSIO, João (1993). "Introdução." Poemas Ingleses. Tomo I. Antinous, Inscriptions, Epithalamium, 35 Sonnets. Ed. de João Dionísio. Edição Crítica de Fernando Pessoa. Lisboa: Imprensa Nacional-Casa da Moeda. 7-37.

DRUCKER, Johanna (1994). The Visible Word: Experimental Typography and Modern Art, 1909-1923. Chicago: The University of Chicago Press. (1995). The Century of Artist's Books. New York: Granary Books.

DUARTE, Luiz Fagundes (1988). "Texto acabado e texto virtual ou a cauda do cometa." Revista da Biblioteca Nacional. S. 2. 3.3 (set.-dez.): 167-181. (2008). "Arca." Dicionário de Fernando Pessoa e do Modernismo Português. Coord. de Fernando Cabral Martins. Lisboa: Caminho. 55-58.

ECO, Umberto (2009). La Vertigine della Lista. Milano: Bompiani: 2009. Trad: A Vertigem das Listas. Trad. de Vergílio Tenreiro Viseu. Lisboa: Difel, 2009.

FEIJÓ, António M. (2000). “'Alberto Caeiro’ e as últimas palavras de Fernando Pessoa." Revista Colóquio/Letras 155/156 (jan.): 181-190.

FOUCAULT, Michel (1994). “Qu'est-ce qu'un auteur?” In Dits et Écrits 19541988. Paris: Gallimard. 789-821. (1. a ed.: 1969, Bulletin de la Societé française de philosophie, 63e année, 3). Trad.: 1992, O que é um autor? Trad. de António Fernando Cascais e Edmundo Cordeiro. Prefácio de José A. Bragança de Miranda e António Fernando Cascais. Lisboa: Vega.

GALHOZ, Maria Aliete (1993). "A fortuna editorial pessoana e seus problemas.” Mensagem. Poemas Esotéricos. Coord. de José Augusto Seabra. Edição Crítica. Madrid [etc.]: Coleção Arquivos. 216-226.

GUSMÃO, Manuel (2003). "O Fausto — um teatro em ruínas.” Românica. Revista de Literatura do Departamento de Literaturas Românicas da FLUL 12: 67-86.

(2011). "Fernando Pessoa e o Original Perdido." Tágides. Revista de Literatura, Cultura e Arte Portuguesas 1. Revisão da História da Literatura e Nova Filologia. São Paulo: Universidade de São Paulo: 89100.

MARTINS, Fernando Cabral (2003). "Breves notas sobre a alta definição." Românica. Revista de Literatura do Departamento de Literaturas Românicas da FLUL 12: 157-164. 
(2011). "Fernando Pessoa e o Original Perdido." Tágides. Revista de Literatura, Cultura e Arte Portuguesas 1. Revisão da História da Literatura e Nova Filologia. São Paulo: Universidade de São Paulo: 89100.

MCGANN, Jerome J. (1993). Black Riders: The Visible Language of Modernism. Princeton, NJ: Princeton University Press.

PATRÍCIO, Rita (2012). Episódios. Da teorização estética em Fernando Pessoa. Edição do Centro de Estudos Humanísticos da Universidade do Minho. V. N. Famalicão: Edições Húmus.

PATRÍCIO, Rita e Jerónimo Pizarro (2006). "Introdução.” Obras de Jean Seul de Méluret. Edição e Estudo de Rita Patrício e Jerónimo Pizarro. Edição Crítica de Fernando Pessoa. Lisboa: Imprensa Nacional-Casa da Moeda. 7-36.

SANTOS, Maria Laura Nobre dos; Cruz, Alexandrina Cruz, Rosa Maria Montenegro e Lídia Pimentel (1988). “A inventariação do espólio de Fernando Pessoa: tentativa de reconstituição." Revista da Biblioteca Nacional S. 2. 3.3 (set.-dez.): 119-213.

SCHERER, Jacques (1977). Le "Livre" de Mallarmé. Nouvelle Édition Revue et Augmentée. Paris: Gallimard.

SEPÚlVEDA, Pedro (2013). Os livros de Fernando Pessoa. Prefácio de António M. Feijó. Lisboa: Ática.

(2013a). "Listas do Desassossego." MATLIT. Revista do Programa de Doutoramento "Estudos Avançados em Materialidades da Literatura" 1.1: 35-55.

SEPÚLVEDA, Pedro e Jorge Uribe (2013). "Planeamento editorial de uma obra em potência: o autor crítico e tradutor Thomas Crosse.” Revista Colóquio/Letras 183: 57-79.

ZENITH, Richard (2001). "Caeiro Triunfal." Alberto Caeiro. Poesia. Ed. de Fernando Cabral Martins e Richard Zenith. Lisboa: Assírio e Alvim. 226266. 